market arose for labour-saving machines. Even today we associate such devices - from the refrigerator to the rubbish compactor - with American values.

Ultimately, Bryson sees precariousness. Our comfortable homes exist today because we consume long-stored fuels, and lots of them.
Of all the energy produced since the Industrial Revolution began, "half has been consumed in the last twenty years" he notes.

Bryson finishes At Home by climbing to his attic and looking out on the world. Climate change is beyond the scope of this book, but he touches on the huge shifts that took place when electricity took over from coal and wood for domestic energy. His home is safe, inland in tranquil Norfolk. But how long will that security endure, if the sea level rises and our resources run out?

David Bodanis is author of $E=m c^{2}$. His next book is on the history of the Ten Commandments.

\title{
Pioneers of plant genetics to flower on stage
}

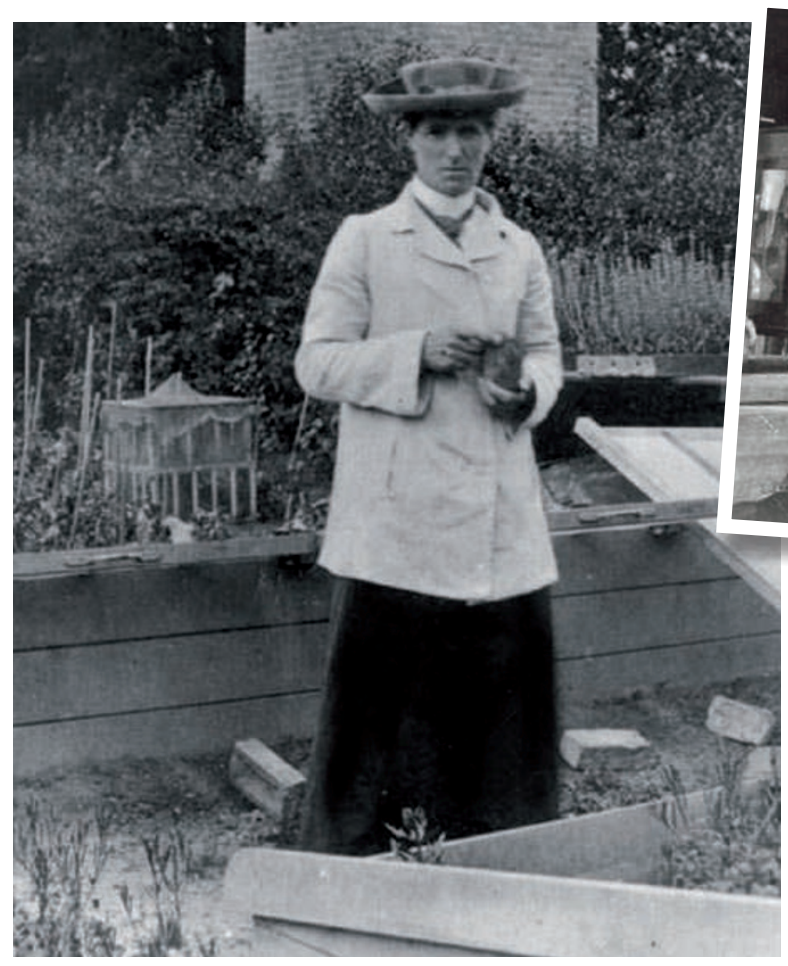

Blooming Snapdragons

by Liz Rothschild. Directed by Sue Mayo 14 July, Royal Institution, London

In the late nineteenth century, a group of female scientists helped to lay the foundations of modern genetics through experiments in plant breeding. Their forgotten story is told in the play Blooming Snapdragons, written by Liz Rothschild and directed by Sue Mayo, which will receive its first London performance at the Royal Institution next week.

Dee Rawsthorne, outreach coordinator at the John Innes Centre in Norwich, UK, commissioned the play to restore the women to their rightful place in the historical record. At a time when higher learning in the sciences was largely closed to females in Britain, the women worked at the University of Cambridge alongside William Bateson, who coined the word

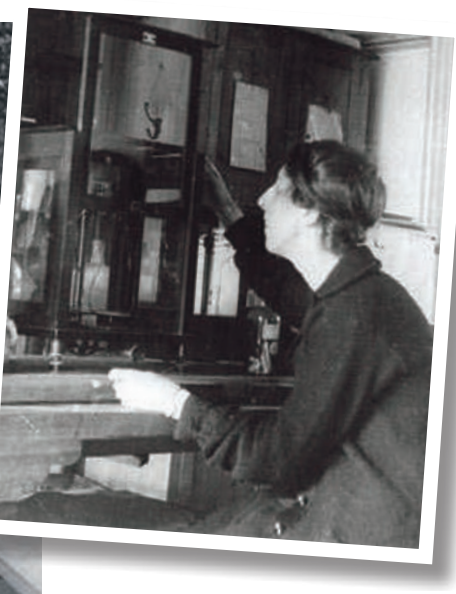

Rebecca Saunders (left) and Muriel Wheldale made vital contributions to early plant genetics.

genetics. He later became the first director of the John Innes Centre's forerunner, the John Innes Horticultural Institution, which was founded in London in 1910.

At Cambridge, Bateson led a programme of mainly plant-based research, where his promotion of the rediscovered Mendelian theory of inheritance made him an outsider. His wife Beatrice was his most devoted assistant, but he also found an able cohort of colleagues among the women who were teaching and studying at the university's Balfour Laboratory, founded for members of the women's colleges in 1884 .

"The Balfour Laboratory was an essential place for women at the end of the nineteenth century," explains Rothschild. "It offered lab space to women students who were banned from other university laboratories and provided a tiny career ladder for female researchers."

The Balfour women included Rebecca Saunders, who in 1920 became the first female president of one of the sections of the British Association for the Advancement of Science; and Muriel Wheldale, who solved the complex inheritance of flower colour in antirrhinums - the 'blooming snapdragons' of the play's title. "These women are sunk in obscurity, and yet they were involved in an area of research that is extremely relevant today," says Rothschild.

In the show, Rothschild and Syreeta Kumar play two modern biologists, Jo and Adi, whose stories are interleaved with those of the historical characters. The dramatic structure turns on the parallels between Bateson's interest in inherited disorders and Adi's experience of genetic disease within her own family. Rothschild, who previously wrote and performed a play about US environmentalist Rachel Carson, drew on research into Bateson's lab by historian Marsha Richmond at Wayne State University in Detroit, Michigan.

I was fascinated to learn of Rothschild's work, having written my own one-woman play for the centenary of the birth of the Nobel prizewinner Dorothy Hodgkin. Hidden Glory was performed on 10 May by Miranda Cook and directed by Abbey Wright at the Oxford University Museum of Natural History, where Hodgkin ran her X-ray lab for more than 20 years.

With access to a huge archive of Hodgkin's letters and other writings, I fashioned a script that used her own words as far as possible, focusing on the work she did on penicillin during the Second World War while her children were very young. Rothschild faced a different challenge: giving voices to women who had left behind much less written material.

Given the powerful emotional engagement that takes place between actor and audience, I believe that theatre should be more extensively exploited in conveying the history of science. Rothschild agrees, adding that, "It has been fascinating to explore the beauty and bravery of the work, and I hope it will kindle in those watching a curiosity in and respect for the challenges facing science now." Georgina Ferry is a writer based in Oxford, UK, and author of the biographies Dorothy Hodgkin: A Life and Max Perutz and the Secret of Life.

See go.nature.com/wQLZHz for more information. 